DOI: $10.28934 /$ jwee19.12.pp1-16

JEL: O11, M13

ORIGINAL SCIENTIFIC PAPER

\title{
An Analysis of the Development of Entrepreneurship in the Republic of Serbia with a Special Focus on Female Entrepreneurship
}

\author{
Jelena Petrović ${ }^{1}$ \\ University of Niš, Faculty of Science and Mathematics, Niš, Serbia \\ Snežana Radukić ${ }^{2}$ \\ University of Nišs, Faculty of Economics, Niš, Serbia
}

\begin{abstract}
A B S T R A C T
Entrepreneurship is a significant factor of the economic development of developed and transition countries. In the literature, special attention is paid to the entrepreneurship development and its impact on the economic growth and economic development of the transition countries. However, insufficient attention is paid to economic growth as a factor of the entrepreneurship development in transition countries. The purpose of the paper is to analyze the impact of economic growth on the entrepreneurship development in the Republic of Serbia and its regions. The results indicated that there is a statistically significant negative correlation between the gross domestic product (GDP) and the number of entrepreneurs as well as between GDP per capita and the number of entrepreneurs in the Republic of Serbia. Also, the results indicated that GDP per capita has a significant impact on the development of female entrepreneurship in the Republic of Serbia.
\end{abstract}

\footnotetext{
${ }^{1}$ Address: Višegradska 33, 18000 Niš, Republic of Serbia, e-mail: jelena25@pmf.ni.ac.rs, tel. +381 6311327 68, 1979

${ }^{2}$ Address: Trg kralja Aleksandra 11, 18000 Niš, Republic of Serbia, e-mail: snezana.radukic@eknfak.ni.ac.rs, tel.+381641494800
} 
KEY WORDS: Entrepreneurship, female entrepreneurship, economic growth, correlation analysis, regression analysis, Republic of Serbia

\section{Introduction}

Fast-growing enterprises or dynamic enterprises are a propeller for the development of the economy. Dynamic companies use their resources more efficiently on the market, increase their employment and quickly respond to market signals by making appropriate business decisions.

The entrepreneurial process is one of the key factors in the economic development of the country/region (Toma, Grigore \& Marinescu, 2013). At today's level of development, economic development and entrepreneurship become strongly interconnected. Lately, there is a growing interest in the concepts of economic development and entrepreneurship in the literature (Acs, Szerb \& Autio, 2013; Szirmai, Naudé \& Goedhuys, 2011; Caree \& Thurik, 2010; Wennekers, van Stel, Carree \& Thurik, 2009).

Economic experts have abandoned the traditional approach that economic development is based on the business of large companies, but small and medium-sized enterprises are considered to be bearers of development in the present time. It is stated that entrepreneurship is a key mechanism for improving economic development, increasing the number of jobs and per capita income (Shane, 2005). "Entrepreneurs need access to resources and markets to succeed, and this is where national policies play a vital role" (Kressel \& Lento, 2012, p. 6).

In the Republic of Serbia, the number of small and medium-sized enterprises increases, as well as their participation in GDP of Serbia. The entrepreneurial sector in Serbia contributes only 1/3 of GDP: in 2017 there were about 242 thousand entrepreneurs, and the largest number in the region of Šumadija and Western Serbia, and then in the Belgrade region (Statistical Yearbook, 2018). Encouraging the development of dynamic entrepreneurship is a development opportunity for Serbia. Primary tasks should be to create a stimulating environment, as well as to solve the key developmental problems of the enterprises in the growth and development phase.

The research presented in this paper is aimed at examining the dynamics of entrepreneurship in Serbia. The aim of the research in dynamic entrepreneurship is to test the primary hypothesis that the economic growth affects on entrepreneurship development. In the first part of the paper a short overview of literature will be given, which points to the importance of inter- 
dependence between entrepreneurship development and economic growth. In the second part of the paper, after the explanation of the models and data, the discussion of the obtained results is followed, as well as recommendations for improving the entrepreneurial sector in Serbia from the point of view of the region and gender.

The main goals of the paper are: 1) analysis of the entrepreneurship development in the Republic of Serbia during the 21st century - total, male and female; 2) analysis of the entrepreneurship development in the regions in the Republic of Serbia; 3) analysis of the interdependence between GDP and the entrepreneurship development in the Republic of Serbia; 4) analysis of the interdependence between GDP per capita and the entrepreneurship development in the Republic of Serbia; 5) analysis of the impact of GDP per capita on the development of female entrepreneurship in the Republic of Serbia; and 6) analysis of interdependence between GDP per capita and the entrepreneurship development in regions of Republic of Serbia.

\section{Literature Review}

In recent decades, increasing attention has been focused on the analysis of the entrepreneurship development in transition countries (Smallbone \& Welter, 2006; 2009), examining the limiting factors of entrepreneurship development in these countries. The entrepreneurship development represents a function of its environment (Morris, 1998), i.e. internal environment as well as the external environment. The institutional environment is identified as one of limiting factors for the entrepreneurship development in transition countries.

During the XXI century, special attention is focused on female entrepreneurship (Delmar, 2003; Marlaw, Coletle \& Carter, 2009; RuminskaZimny, 2002; Ward \& Pampel, 1985). Researchers point to the characteristics of female entrepreneurs in relation to male entrepreneurs (Watson, 2002; Welter, Smallbone, Isakova, Aculai \& Schakirova, 2004). In the literature, special attention is devoted to the analysis of informal institutions that represent a significant factor of the development of female entrepreneurship, especially in transition countries and developing countries. Norms and a value system that is accepted and adopted during the period of central planning are difficult to change (Williams \& Vorley, 2015). Although women in transition countries face similar problems, they have a different position in society in different transition countries (Aidis, Welter, Smallbone \& Isa- 
kova, 2007). The different position in society affects on the development of female entrepreneurship. In the literature, special attention was paid to the influence of informal institutions on female entrepreneurship while analysis of the influence of economic factors on female entrepreneurship is rare, especially in the case of transition countries (Petrović \& Radukić, 2015; Petrović \& Radukić, 2018).

Researches look on the entrepreneurship as an engine of economic development and economic growth (Omoruyi, Olamide, Gomolemo \& Donath, 2017). Entrepreneurship represents a critical factor for the transforming economy from central planning to a market economy.

Based on the link between entrepreneurship and economic growth and development, Faggio and Silva (2014, p. 81) point out that entrepreneurship is "a critical ingredient in determining" of economic growth and economic development. Researches point out 13 significant roles of entrepreneurs (Hebert \& Link, 1989; Dijk \& Thurik, 1995). From the viewpoint of the influence of entrepreneurship on economic growth can be stand out the following rolls: "new entry", i.e. the entrepreneur as creator, organizer and operator of a new business; and "newness", i.e. the entrepreneur as creator of innovation (Wennekers \& Thurik, 1999). Acs and Amoros (2008) indicate that linking between entrepreneurial dynamic and economic growth depending on economic and social situation of the country. The results of their research show that low and middle income countries record a high rate of entrepreneurial activity because the entrepreneurship is the only source of employment for the most population in those countries.

Several researches show a negative influence of economic growth on the entrepreneurship development. These researches were carried out in the 1970s and 1980s, when countries recorded a low level of per capita income (Schultz, 1990; Bregger, 1996). Research carried out at the end of the last century and the beginning of this century points to a positive relationship between per capita income and entrepreneurial activity, because the observed countries recorded a higher level of income per capita (Storey, 1999; Carree, van Stel, Thurik \& Wennekers, 2002). Carree, van Stel, Thurik and Wennekers (2002) and Wennekers, van Stel, Thurik and Reynolds (2005) pointed out that there is a U-shaped relationship between entrepreneurial activity and per capita income. However, the literature does not pay special attention to analysis the relationship between entrepreneurial activity and economic growth in transition countries. This analysis is the subject of research in this paper. 


\section{Methodology}

The following methods were used in the paper: correlation and regression analysis. The correlation analysis enabled the analysis of the interdependence between the number of entrepreneurs and the GDP in the Republic of Serbia, as well as the analysis of the interdependence between the number of entrepreneurs and the GDP per capita in the Republic of Serbia and its regions. In order to quantify the impact of economic growth on the development of female entrepreneurship in the Republic of Serbia, the regression analysis is applied in the paper. The research will use the official data of the Statistical Office of the Republic of Serbia on the number of entrepreneurs towards the sex and region in the Republic of Serbia.

Bearing in mind that the Republic of Serbia is a country of delayed transition it is assumed that has not yet exceeds a certain level or turning point of GDP per capita. After GDP per capita will exceed a turning point, it turns to increase of the number of entrepreneurs as GDP per capita increase. The hypotheses to be tested in this study are the following:

H1: There is a negative correlation between the number of entrepreneurs and GDP per capita in Republic of Serbia;

H2: There is a significant impact of economic growth on female entrepreneurship;

H3: There is a negative correlation between the number of entrepreneurs and GDP per capita all regions in Republic of Serbia.

\section{Data - Analysis of Economic Growth and Entrepreneurial Activity in Republic of Serbia}

Table 1 presents dynamic of GDP and GDP per capita for the observed period. The highest gross domestic product (GDP) measured by dinars was recorded in 2017, while the lowest GDP was recorded 2007. The same situation is with GDP per capita measured by dinars. The observed variables show continuous growth in the observed period. 
Table 1: GDP and GDP per capita

\begin{tabular}{lrrrr}
\hline Year & $\begin{array}{c}\text { GDP } \\
\text { (mil. RSD) }\end{array}$ & $\begin{array}{r}\text { GDP per capita } \\
\text { (RSD) }\end{array}$ & $\begin{array}{c}\text { GDP } \\
\text { (mil. EUR) }\end{array}$ & $\begin{array}{c}\text { GDP per capita } \\
\text { (EUR) }\end{array}$ \\
\hline 2005 & 1747459 & 334849 & 21077 & 2833 \\
2006 & 2042048 & 275522 & 24255 & 3273 \\
2007 & 2302214 & 311886 & 28785 & 3900 \\
2008 & 2722461 & 370392 & 33418 & 4547 \\
2009 & 2815000 & 371555 & 28952 & 3955 \\
2010 & 2881891 & 395243 & 27968 & 3836 \\
2011 & 3208620 & 443541 & 31472 & 4351 \\
2012 & 3584236 & 465155 & 29601 & 4112 \\
2013 & 3876403 & 540902 & 34263 & 4781 \\
2014 & 3908470 & 548035 & 33319 & 4672 \\
2015 & 4043468 & 569873 & 35716 & 5034 \\
2016 & 4261927 & 603816 & 36723 & 5203 \\
2017 & 4754368 & 677178 & 39183 & 5581 \\
\hline
\end{tabular}

Source: Statistical Office of the Republic of Serbia, http://www.stat.gov.rs/sr-latn/

But, if we observed GDP measured by the euro, it can be concluded that GDP decreased 2009 and 2010 which is a consequence the economic crisis. The same situation is when we observe GDP per capita measured by the euro.

Table 2: Regional GDP

\begin{tabular}{|c|c|c|c|c|c|c|c|c|}
\hline \multirow[b]{2}{*}{ Year } & \multicolumn{4}{|c|}{ GDP (in mil. din) } & \multicolumn{4}{|c|}{ GDP per capita (thousand din) } \\
\hline & $\begin{array}{c}\text { Belgrade } \\
\text { region }\end{array}$ & $\begin{array}{l}\text { Region of } \\
\text { Vojvodina }\end{array}$ & $\begin{array}{c}\text { Region of } \\
\text { Šumadija } \\
\text { and } \\
\text { Western } \\
\text { Serbia }\end{array}$ & $\begin{array}{l}\text { Region of } \\
\text { Southern } \\
\text { and East- } \\
\text { ern Ser- } \\
\text { bia }\end{array}$ & $\begin{array}{c}\text { Belgrade } \\
\text { region }\end{array}$ & $\begin{array}{l}\text { Region of } \\
\text { Vojvodina }\end{array}$ & $\begin{array}{c}\text { Region of } \\
\text { Šumadija } \\
\text { and } \\
\text { Western } \\
\text { Serbia }\end{array}$ & $\begin{array}{c}\text { Region of } \\
\text { Southern } \\
\text { and East- } \\
\text { ern Ser- } \\
\text { bia }\end{array}$ \\
\hline 2009 & 1124565 & 720301 & 563734 & 406400 & 690 & 366 & 275 & 243 \\
\hline 2010 & & 8673 & 11 & 418302 & 703 & 382 & 276 & 253 \\
\hline 2011 & & 8 & & & 772 & & 301 & 285 \\
\hline 201 & & 3800 & & & 85 & 507 & 338 & 315 \\
\hline 2013 & & 55270 & 6 & & 926 & 552 & 365 & 342 \\
\hline 2014 & 1 & 70479 & 7701 & 5 & 904 & 563 & 387 & 352 \\
\hline 2015 & 1590947 & 1060389 & 809774 & 579655 & 947 & 561 & 374 & 374 \\
\hline 2016 & 1696449 & 1117298 & 843022 & 602511 & 1007 & 594 & 392 & 392 \\
\hline
\end{tabular}

Source: Statistical Office of the Republic of Serbia, http://www.stat.gov.rs/sr-latn/ 
The highest GDP per capita recorded in Belgrade region and the lowest in Region of Southern and Eastern Serbia. Although, observed regions recorded the continuous growth of GDP per capita, data indicate that regional gap is increased. About $40 \%$ of the GDP of Republic Serbia is realized in the Belgrade region and only $14 \%$ in Region of Southern and Eastern Serbia.

Table 3 presents the development of entrepreneurship and female entrepreneurship in Republic of Serbia in the XXI century. The data indicate that the highest number of entrepreneurs as well as female and male entrepreneurs recorded in 2008. From 2008 to 2015, the number of entrepreneurs has decreased. The number of female entrepreneurs has decreased from 2009 to 2014.

Table 3: Entrepreneurs, male and female entrepreneurs

\begin{tabular}{crrr}
\hline Year & $\begin{array}{c}\text { Number of } \\
\text { entrepreneurs }\end{array}$ & $\begin{array}{c}\text { Number of female } \\
\text { entrepreneurs }\end{array}$ & $\begin{array}{c}\text { Number of male } \\
\text { entrepreneurs }\end{array}$ \\
\hline 2005 & 522493 & 226939 & 295554 \\
2006 & 553877 & 236664 & 317213 \\
2007 & 569494 & 241992 & 327502 \\
2008 & 571019 & 242739 & 328280 \\
2009 & 492293 & 209391 & 282902 \\
2010 & 441138 & 185901 & 255237 \\
2011 & 403246 & 176471 & 226775 \\
2012 & 385934 & 170884 & 215050 \\
2013 & 377081 & 166312 & 210769 \\
2014 & 373855 & 166091 & \\
2015 & 308863 & -1 & \\
2016 & 323313 & - & \\
2017 & 342457 & - & \\
\hline
\end{tabular}

1 - For the period of 2015 to 2017, data about female entrepreneurs in Republic of Serbia do not exist on the site of Statistical Office of the Republic of Serbia.

Source: Statistical Office of the Republic of Serbia, http://www.stat.gov.rs/sr-latn/ 
Table 4: Entrepreneurs in regions in Republic of Serbia

\begin{tabular}{lrrrr}
\hline Year & $\begin{array}{c}\text { Belgrade } \\
\text { Region }\end{array}$ & $\begin{array}{c}\text { Region of } \\
\text { Vojvodina }\end{array}$ & $\begin{array}{c}\text { Region of } \\
\text { Sumadija and } \\
\text { Western Serbia }\end{array}$ & $\begin{array}{c}\text { Region of } \\
\text { Southern and } \\
\text { Eastern Serbia }\end{array}$ \\
\hline 2005 & 142852 & 144018 & 143605 & 92018 \\
2006 & 158726 & 147154 & 147222 & 100776 \\
2007 & 162842 & 155632 & 151203 & 99823 \\
2008 & 162630 & 157415 & 151258 & 99716 \\
2009 & 140268 & 135561 & 130459 & 86005 \\
2010 & 127795 & 121600 & 115981 & 75768 \\
2011 & 115702 & 106172 & 110118 & 71256 \\
2012 & 98101 & 96892 & 112819 & 78122 \\
2013 & 90820 & 96551 & 112392 & 77319 \\
2014 & 89270 & 98248 & 110493 & 75844 \\
2015 & 69976 & 80119 & 94482 & 64286 \\
2016 & 73581 & 82749 & 99387 & 67596 \\
2017 & 79459 & 87135 & 105051 & 70813 \\
\hline
\end{tabular}

Source: Statistical Office of the Republic of Serbia, http://www.stat.gov.rs/sr-latn/

The highest number of entrepreneurs recorded in Region of Šumadija and Western Serbia and the lowest number of entrepreneurs recorded in Region of Southern and Eastern Serbia. The number of entrepreneurs recorded the increase in all regions except in Region of Southern and Eastern Serbia in the period of 2005 to 2008. Those regions recorded decrease of the number of entrepreneurs from 2009 to 2015. In 2016 and 2017, all regions recorded increase of the number of entrepreneurs.

\section{Results and Discussion}

Results of correlation analysis have confirmed the hypothesis $\mathrm{H} 1$ pointing out that there the negative significant correlation between GDP per capita and number of entrepreneurs. The same time, the results of correlation analysis indicate that there the negative significant correlation between GDP and number of entrepreneurs; between GDP and number of female entrepreneurs and between GDP per capita and number of female entrepreneurs. From the viewpoint of relationship between GDP per capita and entrepreneurs, it can be concluded that the relationship between GDP per capita and 
the number of male entrepreneurs is stronger than between GDP per capita and number of female entrepreneurs. The results show that Serbia has not exceed the level of GDP per capita, where increase of GDP per capita would contribute to the increase in the number of entrepreneurs.

Table 5: Independence between GDP, GDP per capita, number of entrepreneurs and number of female entrepreneurs

\begin{tabular}{|c|c|c|c|c|c|c|}
\hline & & $\begin{array}{l}\text { GDP } \\
\text { (mil. } \\
\text { din) }\end{array}$ & $\begin{array}{c}\text { GDP per } \\
\text { capita } \\
\text { (thousand } \\
\text { din.) }\end{array}$ & Entrepreneurs & $\begin{array}{c}\text { Female entre- } \\
\text { preneurs }\end{array}$ & $\begin{array}{l}\text { Male entre- } \\
\text { preneurs }\end{array}$ \\
\hline \multirow{3}{*}{$\begin{array}{l}\text { GDP } \\
\text { (mil.din) }\end{array}$} & $\begin{array}{l}\text { Pearson } \\
\text { Correlation }\end{array}$ & 1 & $.973^{* *}$ & $-.902^{* *}$ & $-.870^{* *}$ & $-.863^{* *}$ \\
\hline & $\begin{array}{l}\text { Sig. (2- } \\
\text { tailed) }\end{array}$ & & .000 & .000 & .001 & .001 \\
\hline & $\mathrm{N}$ & 13 & 13 & 13 & 10 & 10 \\
\hline \multirow{3}{*}{$\begin{array}{l}\text { GDP per } \\
\text { capita (thou- } \\
\text { sand din) }\end{array}$} & $\begin{array}{l}\text { Pearson } \\
\text { Correlation }\end{array}$ & $.973^{* *}$ & 1 & $-.914^{* *}$ & $-.896^{* *}$ & $-.909^{* *}$ \\
\hline & $\begin{array}{l}\text { Sig. (2- } \\
\text { tailed) }\end{array}$ & .000 & & .000 & .000 & .000 \\
\hline & $\mathrm{N}$ & 13 & 13 & 13 & 10 & 10 \\
\hline \multirow{3}{*}{ Entrepreneurs } & $\begin{array}{l}\text { Pearson } \\
\text { Correlation }\end{array}$ & $.902^{* *}$ & $-.914^{* *}$ & 1 & $.997^{* *}$ & $.999^{* *}$ \\
\hline & $\begin{array}{l}\text { Sig. (2- } \\
\text { tailed) }\end{array}$ & .000 & .000 & & .000 & .000 \\
\hline & $\mathrm{N}$ & 13 & 13 & 13 & 10 & 10 \\
\hline \multirow{3}{*}{$\begin{array}{l}\text { Female entre- } \\
\text { preneurs }\end{array}$} & $\begin{array}{l}\text { Pearson } \\
\text { Correlation }\end{array}$ & $.870^{* *}$ & $-.896^{* *}$ & $.997^{* *}$ & 1 & $.993^{* *}$ \\
\hline & $\begin{array}{l}\text { Sig. (2- } \\
\text { tailed) }\end{array}$ & .001 & .000 & .000 & & .000 \\
\hline & $\mathrm{N}$ & 10 & 10 & 10 & 10 & 10 \\
\hline \multirow{3}{*}{$\begin{array}{l}\text { Male entre- } \\
\text { preneurs }\end{array}$} & $\begin{array}{l}\text { Pearson } \\
\text { Correlation }\end{array}$ & $.863^{--}$ & $-.909^{* *}$ & $.999^{* *}$ & $.993^{* *}$ & 1 \\
\hline & $\begin{array}{l}\text { Sig. (2- } \\
\text { tailed) }\end{array}$ & .001 & .000 & .000 & .000 & \\
\hline & $\mathrm{N}$ & 10 & 10 & 10 & 10 & 10 \\
\hline
\end{tabular}

**. Correlation is significant at the 0.01 level (2-tailed).

Source: Prepared by the authors (SPSS Statistics 19)

The results of regression analysis, i.e. the impact of GDP per capita on development of female entrepreneurship are given in Table 6 . The value of the observed regression coefficient is statistically significant because the Sig. value is less than 0.01 . The hypothesis H2 is supported. 
Table 6: The value of regression coefficients - influence of the GDP per capita on the development of female entrepreneurship

\begin{tabular}{lccccc}
\hline Model & R & R Square & $\begin{array}{c}\text { Adjusted R } \\
\text { Square }\end{array}$ & $\begin{array}{c}\text { Std. Error of } \\
\text { the Estimate }\end{array}$ & Sig. \\
\hline 1 & $.896^{\mathrm{a}}$ & .803 & .779 & 15351.29187 & .000 \\
\hline
\end{tabular}

a. Predictors: (Constant), GDP per capita

b. Dependent Variable: number of female entrepreneurs

Source: Prepared by the authors (SPSS Statistics 19)

Table 7: Interdependence between GDP per capita and number of entrepreneurs in Belgrade region

\begin{tabular}{llrr}
\hline & & GDP per capita & Entrepreneurs \\
\hline \multirow{2}{*}{ GDP per capita } & Pearson Correlation & 1 & $-.973^{* *}$ \\
& Sig. (2-tailed) & & .000 \\
& $\mathrm{~N}$ & 8 & 8 \\
\hline \multirow{2}{*}{ Entrepreneurs } & Pearson Correlation & $-.973^{* *}$ & 1 \\
& Sig. (2-tailed) & .000 & \\
& $\mathrm{~N}$ & 8 & 8 \\
\hline
\end{tabular}

**. Correlation is significant at the 0.01 level (2-tailed).

Source: Prepared by the authors (SPSS Statistics 19)

On the basis of the value of Sig. in Table 7 it can be concluded that there is a statistically significant relationship between the GDP per capita and number of entrepreneurs in Belgrade region. The results of analysis indicate that is negative correlation between observed variables i.e. with the increase in GDP per capita, the number of entrepreneurs is decreasing.

Table 8: Interdependence between GDP per capita and number of entrepreneurs in Region of Vojvodina

\begin{tabular}{llrr}
\hline & GDP per capita & \multicolumn{1}{c}{ Entrepreneurs } \\
\hline \multirow{2}{*}{ GDP per capita } & Pearson Correlation & 1 & $-.931^{* *}$ \\
& Sig. (2-tailed) & & .001 \\
& $\mathrm{~N}$ & 8 & 8 \\
\hline
\end{tabular}




\begin{tabular}{llrr}
\hline & & GDP per capita & Entrepreneurs \\
\hline \multirow{2}{*}{ Entrepreneurs } & Pearson Correlation & $-.931^{* *}$ & 1 \\
& Sig. (2-tailed) & .001 & \\
& $\mathrm{~N}$ & 8 & 8 \\
\hline
\end{tabular}

**. Correlation is significant at the 0.01 level (2-tailed).

Source: Prepared by the authors (SPSS Statistics 19)

Results of correlation analysis have shown that there is statistically significant negative correlation between the GDP per capita and number of entrepreneurs in Region of Vojvodina since the value of Sig. is not less than 0.01 , as indicated in Table 8. We can determine that hypothesis H1 is confirmed.

Table 9: Interdependence between GDP per capita and number of entrepreneurs in Region of Šumadija and Western Serbia

\begin{tabular}{llrr}
\hline & GDP per capita & Entrepreneurs \\
\hline \multirow{2}{*}{ GDP per capita } & Pearson Correlation & 1 & $-.738^{*}$ \\
& Sig. (2-tailed) & & .037 \\
& $\mathrm{~N}$ & 8 & 8 \\
\hline \multirow{3}{*}{ Entrepreneurs } & Pearson Correlation & $-.738^{*}$ & 1 \\
& Sig. (2-tailed) & .037 & 8 \\
& $\mathrm{~N}$ & 8 & \\
\hline
\end{tabular}

*. Correlation is significant at the 0.05 level (2-tailed).

Source: Prepared by the authors (SPSS Statistics 19)

Results of correlation analysis have shown that there is statistically significant negative correlation between the GDP per capita and number of entrepreneurs in Region of Šumadija and Western Serbia since the value of Sig. is not less than 0.01 , as indicated in Table 8. 
Table 10: Interdependence between GDP per capita and number of entrepreneurs in Region of Southern and Eastern Serbia

\begin{tabular}{llrr}
\hline & GDP per capita & Entrepreneurs \\
\hline \multirow{2}{*}{ GDP per capita } & Pearson Correlation & 1 & -.698 \\
& Sig. (2-tailed) & & .054 \\
& $\mathrm{~N}$ & 8 & 8 \\
\hline \multirow{5}{*}{ Entrepreneurs } & Pearson Correlation & -.698 & 1 \\
& Sig. (2-tailed) & .054 & \\
& $\mathrm{~N}$ & 8 & 8 \\
\hline
\end{tabular}

Source: Prepared by the authors (SPSS Statistics 19)

On the basis of the value of Sig. in Table 10 it can be concluded that there is no statistically significant relationship between the GDP per capita and number of entrepreneurs in Region of Southern and Eastern Serbia. We can determine that hypothesis $\mathrm{H} 3$ is not confirmed.

The results of correlation analyzes indicate that the highest statistically significant negative correlation between the observed variable is recorded in Belgrade region. Based on the results of the research it can be concluded that no region has reached the level of GDP per capita whose increase contributes to the increase in the number of entrepreneurs.

\section{Conclusion}

The number of entrepreneurs in the Republic of Serbia in the 21st century is decreasing. The largest number of entrepreneurs was recorded in 2008, and the smallest in 2015. The results indicated that there is a statistically significant negative correlation between the GDP per capita and the number of entrepreneurs in the Republic of Serbia and their regions (except Region of Southern and Eastern Serbia). Also, the results indicated that GDP per capita has a significant impact on the development of female entrepreneurship in the Republic of Serbia.

Bearing in mind that during the 21st century the total number of entrepreneurs is reduced it is necessary to apply adequate measures in order to stimulate the development of entrepreneurship in the Republic of Serbia. Based on the analysis of problems in the development of entrepreneurship in the Republic of Serbia, concrete solutions should be proposed in order to 
eliminate economic, legal and administrative barriers in order to stimulate the development of entrepreneurship and economic growth.

The originality of the work is reflected in the fact that the influence of economic growth on the development of entrepreneurship in the Republic of Serbia will be explored. Particular emphasis will be put on the analysis of the development of entrepreneurship towards the gender and region within the Republic of Serbia. We will try to identify the basic problems in order to identify the necessary measures to stimulate the development of entrepreneurship.

\section{Acknowledgements}

This paper is a result of research project under the code 44007 financed by the Ministry of Education, Science, and Technological Development of the Republic of Serbia.

\section{References}

[1] Acs, J. Zoltan, and José Ernesto Amorós. 2008. "Entrepreneurship and competitiveness dynamics in Latin America." Small Business Economics, 31(3): 305-322.

[2] Acs, J. Zoltan, László Szerb, and Erkko Autio. 2013. Global Entrepreneurship and Development Index. Chelthenham: Edward Elgar Publishing.

[3] Aidis, Ruta, Friederike Welter, David Smallbone, and Nina Isakova. 2007. "Female entrepreneurship in transition economies: The case of Lithuania and Ukraine." Feminist Economics, 13(2): 157-183.

[4] Bregger, E. John. 1996. "Measuring self-employment in the United States." Monthly Labor Review, January/February, 3-9.

[5] Carree, A. Martin, and Roy A. Thurik. 2010. "The Impact of Entrepreneurship on Economic Growth." In Handbook of Entrepreneurship Research, ed. Zoltan J. Acs and David B. Audretsch, 557-594. New York: Springer Science+Media.

[6] Carree, Martin, André van Stel, Roy Thurik, and Sander Wennekers. 2002. "Economic development and business ownership: an analysis using data of 23 OECD countries in the period 1976-1996." Small Business Economics, 19(3): 271-290.

[7] Delmar, Frédéric. 2003. "Women entrepreneurship: assessing data availability and future needs." Paper for the workshop "Improving Statistics on SMEs and Entrepreneurship", OECD, Paris, September 17-19, 2003. 
http://www.oecd.org/std/business-stats/14723090.pdf (accessed June 12, 2015).

[8] Dijk, Bob van, and Roy A. Thurik. 1995. "Entrepreneurship: visies en benaderingen." Research Report 9510/N, Zoetermeer: EIM.

[9] Faggio, Giulia, and Olmo Silva. 2014. "Self-employment and entrepreneurship in urban and rural labour markets." Journal of Urban Economics, 84: 67-85.

[10] Hébert, Robert F., and Albert N. Link. 1989. "In Search of the Meaning of Entrepreneurship." Small Business Economic, (1)1: 39-49.

[11] Kressel, Henry, and Thomas V. Lento. 2012. Entrepreneurship in the Global Economy: Engine for Economic Growth. Cambridge: Cambridge University Press.

[12] Marlow, Susan, Colette Henry, and Sara Carter. 2009. "Exploring the Impact of Gender upon Women's Business Ownership: Introduction." International Small Business Journal, 27(2): 139-148.

[13] Morris, H. Michael. 1998. Entrepreneurial Intensity: Sustainable Advantage for Individuals, Organizations and Societies. Quorum, Westport: CT.

[14] Omoruyi, Ehizuelen Michael Mitchell, Olamide, K. S., Gomolemo, G., and Donath, O. A. 2017. "Entrepreneurship and Economic Growth: Does Entrepreneurship Bolster Economic Expansion in Africa?" Journal of Socialomics, 6(4): 219-230.

[15] Petrović, Jelena, and Snežana Radukić. 2015. "Multicriteria analysis of female entrepreneurship in transition economies: The case of Central Europe and Baltic States." Paper presented at IV REDETE Conference: Researching economic development and entrepreneurship in transitional economies, ed. Jovo Ateljević and Jelena Trivić, 1041-1053. Graz, Austria: Faculty of Economics, University of Banja Luka.

[16] Petrović, Jelena, and Snežana Radukić. 2018. "The Distinctiveness of Female Entrepreneurship in Post-Transition Countries: The Case of Central Europe and the Baltic States." In Entrepreneurship in Post-Communist Countries: New Drivers towards a Market Economy, ed. Jovo Ateljević and Jelena Budak, 99-114. Cham, Switzerland: Springer.

[17] Ruminska-Zimny, Ewa. 2002."Women's entrepreneurship and labour market trends in transition countries." In Women's Entrepreneurship in Eastern Europe and CIS Countries, 7-22. Geneva: United Nations.

[18] Schultz, T. Paul. 1990. "Women's changing participation in the labor force: a world perspective." Economic Development and Cultural Change, 38(3): 457-488.

[19] Shane, Scott. 2005. (ed.) Economic Development through Entrepreneurship. Chelteham: Edward Elgar. 
[20] Smallbone, David, and Friederike Welter. 2006. "Conceptualizing entrepreneurship in a transition context." International Journal of Entrepreneurship and Small Business, 3(2): 190-206.

[21] Smallbone, David, and Friederike Welter. 2009. Entrepreneurship and Small Business Development in Post-Socialist Economies. London and New York: Routledge.

[22] Statistical Office of the Republic of Serbia. 2018. Statistical Year 2018. http://publikacije.stat.gov.rs/G2018/Pdf/G2182051.pdf (accessed April 12, 2018).

[23] Statistical Office of the Republic of Serbia. http://www.stat.gov.rs/sr-latn/ (accessed April 12, 2018).

[24] Storey, J. David. 1999. "Six steps to heaven: evaluating the impact of public policies to support small business in developed economies." In Handbook of Entrepreneurship, ed. Donald L. Sexton and Hans Landström, 176-194. Oxford: Blackwell.

[25] Szirmai, Adam, Wim Naudé, and Micheline Goedhuys. 2011. (ed.) Entrepreneurship, Innovation, and Economic Development. Oxford: Oxford University Press.

[26] Toma, Sorin-George, Ana-Maria Grigore, and Paul Marinescu. 2014. "Economic development and entrepreneurship." Procedia Economics and Finance, 8: 436-443.

[27] Ward, B. Kathryn, and Fred C. Pampel. 1985. "Structural determinants of female labor force participation in developed nations, 1955-1978.” Social Science Quarterly, 66(3): 654-667.

[28] Watson, John. 2002."Comparing the Performance of Male and Female Controlled Businesses: Relating Outputs to Inputs." Entrepreneurship, Theory and Practice, 26(3): 91-100.

[29] Welter, Friederike, David Smallbone, Nina Isakova, Elena Aculai, and Natalja Schakirova. 2004. "Female entrepreneurship in the Ukraine, Moldova and Uzbekistan: Characteristics, Barriers and Enabling Factors and Policy Issues." In Women Entrepreneurs in the ECE Region, ed. UNECE, 93-52. Geneva: United Nations.

[30] Wennekers, Sander, and Roy Thurik. 1999. "Linking entrepreneurship and economic growth." Small Business Economics, 13(1): 27-55.

[31] Wennekers, Sander, André van Stel, Martin Carree, and Roy Thurik. 2009. The relationship between entrepreneurship and economic development: is it U-shaped? http://www.icesstudy.org/WhatIsEnterpreneurship/Research/\%28knowledge \%20web\%29\%20the\%20relationship\%20between\%20enteprenurship\%20an d\%20economic\%20development.pdf (accessed October 30, 2018). 
[32] Wennekers, Sander, André van Stel, Roy Thurik, and Paul Reynolds. 2005. "Nascent Entrepreneurship and the Level of Economic Development." Small Business Economics, 24(3): 293-309.

[33] Williams, Nick, and Tim Vorley. 2015. "Institutional asymmetry: How formal and informal institutions affect entrepreneurship in Bulgaria." International Small Business Journal, 33(8): 840-861.

Article history: $\quad$ Received: 23 February, 2019

Accepted: 18 May, 2019 